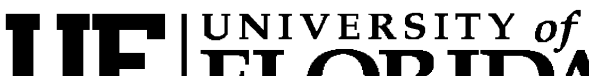 FLORIDA \\ IFAS Extension
}

$\mathrm{PI}-134$

\section{Florida Fungicide Pricing and Expectations ${ }^{1}$}

\section{A. Mossler ${ }^{2}$}

The following list (Table 1) has been compiled from various unnamed sources. Each price reflects a blend of the differing use rates for differing crops and sites. Sites where more active ingredient is used per spray (orchards) may have higher costs than those for other crop sites. Likewise, if an active ingredient is used in a specialty site such as golf course, turf, or ornamental, it is likely to cost more per application.

It is important to appreciate the expectations users have for each active ingredient, which is reflected in the price. Materials used as scheduled, prophylactic preventative sprays (e.g. captan, thiram, maneb, mancozeb, coppers, sulfur) generally average between $\$ 5 /$ acre and $\$ 10 /$ acre.

Materials that give protection from a variety of leaf diseases and control key diseases generally range from $\$ 10 /$ acre to $\$ 40 /$ acre; but even within similar chemistries prices may vary for several reasons. In the case of strobilurin fungicides, azoxystrobin is labeled for many more crops than the others and has a zero-day pre-harvest interval (PHI) for most crops. Pyraclostrobin is registered on fewer crops, and trifloxystrobin has a 30-day PHI for citrus, the main crop for which it is used in Florida. The longer the
PHI, the less flexibility the grower has near harvest. Consequently, there are substantial differences for the pricing of these fungicides.

Materials that are unique (e.g. acibenzolar, mefenoxam, fenhexamid) and manage key pests of high dollar crops or sites generally cost the most, starting at around $\$ 40 /$ acre and increasing. Prices for turf/ornamental fungicides (e.g. fenarimol, iprodione), often labeled in terms of ounces per 1,000 square feet can range from $\$ 50$ to $\$ 150$ when converted to an acre basis.

1. This document is PI-134, one of a series of the Pesticide Information Office, Florida Cooperative Extension Service, Institute of Food and Agricultural Sciences, University of Florida. Original publication date September 2006. Visit the EDIS Web Site at http://edis.ifas.ufl.edu.

2. Mark A. Mossler, Doctor of Plant Medicine, Pesticide Information Office, Agronomy Department; Florida Cooperative Extension Service, Institute of Food and Agricultural Sciences, University of Florida, Gainesville, FL 32611-0710.

The use of trade names in this publication is solely for the purpose of providing specific information. UF/IFAS does not guarantee or warranty the products named, and references to them in this publication does not signify our approval to the exclusion of other products of suitable composition. Use pesticides safely. Read and follow directions on the manufacturer's label.

The Institute of Food and Agricultural Sciences (IFAS) is an Equal Opportunity Institution authorized to provide research, educational information and other services only to individuals and institutions that function with non-discrimination with respect to race, creed, color, religion, age, disability, sex, sexual orientation, marital status, national origin, political opinions or affiliations. U.S. Department of Agriculture, Cooperative Extension Service, University of Florida, IFAS, Florida A. \& M. University Cooperative Extension Program, and Boards of County Commissioners Cooperating. Larry Arrington, Dean 
Table 1.

\begin{tabular}{|c|c|}
\hline Active Ingredient & Price (\$/acre) \\
\hline ACIBENZOLAR & 41.90 \\
\hline AZOXYSTROBIN & 21.36 \\
\hline Bacillus subtilis & 12.03 \\
\hline BOSCALID & 23.41 \\
\hline CAPTAN & 10.75 \\
\hline CHLOROTHALONIL & 18.00 \\
\hline COPPER HYDROXIDE & 6.52 \\
\hline COPPER OXYCHLORIDE S & 8.31 \\
\hline COPPER SULFATE & 5.05 \\
\hline CYMOXANIL & 4.14 \\
\hline CYPRODINIL & 34.80 \\
\hline DIMETHOMORPH & 6.11 \\
\hline FAMOXADONE & 5.35 \\
\hline FENBUCONAZOLE & 11.93 \\
\hline FENARIMOL & 150.00 \\
\hline FENHEXAMID & 44.48 \\
\hline FERBAM & 37.93 \\
\hline FLUDIOXONIL & 19.57 \\
\hline FOSETYL & 19.93 \\
\hline HYDROGEN PEROXIDE & 33.38 \\
\hline IPRODIONE & 50.00 \\
\hline MANCOZEB & 4.08 \\
\hline MANEB & 4.32 \\
\hline MEFENOXAM & 43.02 \\
\hline MYCLOBUTANIL & 18.28 \\
\hline NEEM OIL & 20.84 \\
\hline PETROLEUM OIL & 11.22 \\
\hline PHOSPHORIC ACID & 9.96 \\
\hline POTASSIUM CARBONATE & 42.50 \\
\hline PROPICONAZOLE & 4.85 \\
\hline PYRACLOSTROBIN & 14.21 \\
\hline PCNB & 8.98 \\
\hline SULFUR & 8.08 \\
\hline TEBUCONAZOLE & 12.07 \\
\hline THIOPHANATE-METHYL & 13.45 \\
\hline THIRAM & 9.29 \\
\hline TRIFLOXYSTROBIN & 7.14 \\
\hline TRIFLUMIZOLE & 17.63 \\
\hline
\end{tabular}

